\title{
Investment decision by using Capital Asset Method Pricing Model (CAPM) (Case studies on five automotive companies listed in stock exchange)
}

\author{
Ahmad Musodik*, Arrum Puspita Sari, Ida Nur Fitriani \\ UIN Raden Mas Said Surakarta, Surakarta, Indonesia
}

\begin{abstract}
Article History
Received : 30 June 2021

Revised : 21 August 2021

Accepted : 26 August 2021

Published : 27 August 2021
\end{abstract}

\section{Keywords:}

Capital asset pricing model, beta, expected return, overvalued, undervalued

\section{Corresponding author:}

ahmadmusodik105@gmail.com

DOI:

10.20885/AMBR.vol1.iss2.art8

\begin{abstract}
Investment is a tool for investors to get more profit than what has been invested. Investors must be able to predict the possibilities that occur when investing. Capital Asset Pricing Model is a tool to predict the development of investment in a particular company used to calculate and determine the Expected Return in minimizing risk investments. The authors conducted research using a sample of 5 companies in the automotive industry, namely PT Astra International Tbk, PT Indokordsa Tbk, PT Indomobil Sukses Internasional Tbk, PT Astra Otoparts Tbk, and PT Gajah Tunggal Tbk. This study uses a descriptive quantitative approach with Microsoft Excel 2016 analysis tools. This study aims to determine Portfolio Analysis with the Capital Asset Pricing Model (CAPM) approach which is used as the basis for making stock investment decisions in automotive industry sector companies listed on the Indonesia Stock Exchange. Use from the results of the analysis of the results by comparing the value of $\mathrm{E}(\mathrm{Ri})$ has a directly proportional relationship, meaning that the higher the value of, then the stock return $(\mathrm{E}(\mathrm{Ri}))$ will be high as well. Of the 5 companies, there are 2 companies that are in the Undervalued category and 3 companies that are in the overvalued category. This means that investors who will invest in companies engaged in the automotive industry can decide to buy shares of the companies PT Indomobil Sukses Internasional Tbk and PT Gajah Tunggal Tbk, because they are classified as undervalued. Meanwhile, investors who want to invest in shares are not advised to buy company shares that are in the overvalued category, but are advised to sell them to investors who already have shares in the company.
\end{abstract}

\section{Introduction}

In the business world, the company is highly dependent on the investment. Both have contributed in the development of a business carried on. The purpose of doing both is to get a greater advantage than on invested now. Ability of analysis an investor prior to such investors decided the investment will be carried out (Azizah, 2007).

The development of the company in Indonesia is very rapid, as evidenced by the achievements obtained indonesia entersin category as of the state of the industry, with meyumbangkan $20 \%$ for the economy nasoional, and in the category of countries the ranks of the world's elite. Sector of the automotive industry including companies that have a good development (Putri, 2015). With the development of today's technology and the level of needs of consumers in the automotive world makes the automotive company has good opportunities for an investor to invest, of course, invest in a company that has been listed on the Indonesia stock Exchange.

As a smart investor, should always deepen the insight, the update of the information received, and observant in seeing the potential profit to be obtained. Investors who want to plunge in investment in the capital market, especially in the field of buying and selling shares should be 
able to use the mind in a rational way to analyze the shares which will be purchased will determine the amount of profit that will be obtained in the future (Liwe, et al. 2021).

In every investment decision is required considerations such as financial information, calculations and analyses that are adequate to choose a stock investment that promises the rate of profit with the level of risk specific. In addition, investment in the capital market is an investment that quite risky, because of the condition of the stock price always fluctuate as a result of the uncertainty in the capital market affect the stock price (Septiana, et al. 2018). This uncertainty is influenced by several factors, among others: future conditions of the company, capital market conditions, and the economy of a country.

In other words, options investing stock does not rely only on the level of expected profit but should also consider the risk factors. For that in investing should investors choose stocks that are efficient, that is, stocks that provide the level of profit with a certain level of risk to the minimum, or give certain risks with the maximum profit (Susanti, et al. 2021). One of the methods that can be used is the Analysis of the Portfolio.

Portfolio analysis is a very important thing for any investment because it can be used as a basis to diversify their stock so that it can produce a composition that efficient means of expected return (the return expected) maximum on the level of risk or the level of risk to a minimum, which resulted in a return specific. One of the methods to calculate the rate of profit (return) to risk (risk) securities of the method is to use the Capital Asset Pricing Model (CAPM) (Dempsey, 2013).

Capital Asset Pricing Model (CAPM) is a set of predictions concerning equilibrium estimates of the returns to risky assets. The main purpose of the application of the CAPM is to determine the level of expected return in minimizing investment risk. The CAPM can also help investors in calculating the risk which cannot be diversified in a portfolio and compare it with the predictions of the rate of return (return) (Barberis, et al. 2015). By looking at the importance of portfolio analysis with the approach of the CAPM to investors for the determination of the investment in the capital market, it is expected portfolio analysis with the approach of the CAPM can help the investors in taking investment decisions (Kisman \& Restiyanita, 2015).

From the background of the problem as previously described, the authors formulate the problem as follows: "How to influence the Analysis of the Portfolio approach to Capital Asset Pricing Model (CAPM) to decision making stock investments in Pcompany Astra international Tbk, Astra Otoparts Tbk, Indo Kordsa Tbk, Gajah Tunggal Tbk, and the Indomobil sukses international Tbk."

\section{Literature Review and Hypotheses Development}

\section{Understanding Capital Markets}

The Capital market is the activity between the owner of the funds with those who need funds that buy and sell securities (Tandelilin, 2010). The Capital market is a means that can be used to collect funds from the public, for the company's capital market can be used to alternate on long-term financing, and to capital market investors is a means to make the investment of funds with how to choose a good stock that has a high profit, the lack of risk in order to benefit obtained the greater.

\section{The Purpose and Function of the Capital Market}

The purpose of the capital market, namely bridging the flow of funds between the two parties namely the owner of the funds and those who need funds (Susanti, et al. 2020). Functions of capital market:

1. The function of economy: the market provides the facility/vehicle that brings together the two interests, that is, between the owner of the funds and those who need funds. The presence of capital market, the owner of the funds will acquire a return and the company will utilize the funds.

2. The functions of finance: capital market provides the possibility and opportunity to obtain the return for the owners of the funds according to the characteristics of the selected investment. 


\section{Understanding Investment}

The investment comes the word "Invest" what it means to grow, planting the money or invest. Investment is a term in use in the world of business and investment is usually used in the fill in the legislation. Investment is the commitment in a number of funds/other resources and implementation at the moment, and hoping to get a profit in the future (Tandelilin, 2001).

Benefits in investing are:

1. Earn profits in the future.

2. Help reduce inflationary pressures.

The process should be carried out in investing is to determine the purpose of investing, do the analysis, do the portfolio formation, perform the performance of the portfolio, revised the performance of the portfolio. In investing, there are risks of investing. Risk is the possibility of deviation of the rate of profit of the real rate of return expected so it will reduce the profit/failure on investors (Hundal, et al. 2019). The risk for:

1. The risk is not systematic, i.e. the risk that can be avoided by investors with diversification.

2. The risk of systematic, i.e. the risk that can not be avoided by investors, due to macroeconomic conditions of the country/outside of the company.

\section{Understanding Portfolio}

A portfolio is a collection of investments or a collection of investment instruments that are formed to meet a target of the investment portfolio. Steps to perform the construction of an investment: (Wu, et al. 2017)

1. Choosing investment instruments that are in demand.

2. Determine the weight of investment instruments to the value of the overall portfolio.

3. Determine the investment horizons.

4. Determine the expected return of each investment instrument in accordance investment horizons.

5. Determine the expected return of the portfolio in accordance investment horizons.

6. Determine the average expected return of the portfolio in accordance investment horizons.

7. Calculate the standard deviation of the expected return of the portfolio.

\section{Capital Asset Pricing Model (CAPM)}

There are a few benchmarks to calculate stock return one of them is CAPM. CAPM include the equity risk on a minimum return. If the stock is high risk, the smaller the minimum return. Capital Asset Pricing Model (CAPM) is a model of a model to determine the prices of assets in a state of ekuilibium or analysis of the stock through the risk of its systematic (risk are not the same can be avoided by investors). The CAPM provides an overview quickly in the play the magnitude of the advantage given by the company (Jogiyanto, 2008).

The CAPM formula, namely:

$$
\text { Expecteed Return }=\text { Cost of Equity }=R f+\beta *\left(R_{m}-R_{f}\right)
$$

Where:

Rf $\quad$ : Risk-free rate (investment without risk)

$\beta$ (beta) :Nondiversifiablerisk (systematic risk that cannot be eliminated through diversification by investors)

Rm :Market Return

\section{The Relationship between Risk and Profit in the Scope of CAPM}

According to Jogiyanto (2008), the measurement of risk in the CAPM, namely using beta (B) as a measure of risk. Efficient investment is an investment that gives a certain risk with the level of maximum profits or certain profit levels with minimum risk. If there are two investment proposals that provide the same profit level, but have a different risk, then investors will rationally choose the investment that has risilto smaller. 
Security Market Line (SML) shows the relationship between risk and the level of benefits to all securities, whether efficient or not efficient. SML is a depiction of a line of the CAPM model, where the SML illustrates the trade off between risk with the expected return for individual securities can be identified as the beta ( $(\beta)$ of such shares. Beta ( $($ ) determine the magnitude of the additional expected return for individual securities with the argument that portfolio in diversification are perfectly and the relevant risk only systematic risk measured by beta (Ayub, et al. 2020).

The Beta for the market portfolio is the value-1 $(B \mathrm{~m}=\mathrm{a} 2 \mathrm{~m}=\mathrm{I})$. A security which has a $(B<\mathrm{I})$ is said to be at risk is smaller than the risk of the market portfolio. Conversely, if has the value $(\beta>I)$ is said to have systematic risk is greater than the risk of the market. If a security has a beta equal to the beta of market portfolio $(B \mathrm{~m}=\mathrm{I})$, expected securities have an expected return equal to expected return of market portfolio $\mathrm{E}(\mathrm{Rm})$ (Agouram, et al. 2020). The relationship of expected return and beta can be described underlined the securities market (SML).

\section{The Advantage Using CAPM Approach in Decision-Making}

CAPM (Capital Asset Pricing Model) is a model for determining the price of a security. CAPM Model basing themselves on the condition of balance (equilibrium). The price of shares worth on the stock exchange is the amount of the dividend divided by the result of the add with the interest raised to the power of year-to-n, according to Alifiani (2017) in the formulation can be written as follows: (Yu, 2017)

Formula: $\mathrm{Po}_{\mathrm{O}}=\sum \mathrm{D} /(1+\mathrm{r})^{1}$

Where:

Po $=$ Price of the stock on the stock exchange today

D1 = Dividend

$\mathrm{r} \quad=$ Interest

$\mathrm{t}=$ Period of the year to the-n

According to $\mathrm{Yu}(2017)$ the characteristics of the investors investing in stocks faced three groups:

1) Happy face the risk;

2) Avoid the risk, and;

3) Be neutral against the risk.

That became the thinking of investors whether the funds invested will give you the optimal benefit. An investment that has a high level of risk, an investor would expect the rate of profit is also high.

\section{Research Methods}

The kind of Research done by the researchers is a quantitative research. Sources of data in this study comes from the secondary data obtained dari Bursa efek Indonesia (BEI).

\section{Population and Sample}

In this study, the sample used is the 5 Companies of the Automotive Industry listed in Indonesia stock Exchange (BEI).

\section{Data Collection Procedures}

- Literature Study

The authors obtain or collect data by way of studying carefully and thoroughly for the knowledge of the scientific and other literature in connection with this research.

- Documentation

The data obtained made and processed by the Indonesia stock Exchange (BEI) in the form of reports of the trading price of the stock 5 Companies of the Automotive Industry listed in Indonesia stock Exchange (BEI). 


\section{Data Analysis Techniques}

- Calculate Rate of Return of Individual Stocks

Calculate the rate of return of individual stock based on the Closing Stock Price, with the formula: (Pebriani, et al. 2018)

Description:

$$
Y=R i=\frac{\operatorname{HSi}(\mathrm{t} 1)-\operatorname{HSi}(\mathrm{t} 0)}{\mathrm{JCI}(\mathrm{t} 0)}
$$

$\mathrm{Y}=\mathrm{Ri}=$ Rate of return of each company. $(\mathrm{R}$ is based on the advantages of individual stocks 1 each of the company)

$\mathrm{HSi}(\mathrm{tl})=$ the closing Price of the individual stock is the present period

$\mathrm{HSi}(\mathrm{t} 0)=$ the closing Price of the individual stocks last period

- Calculate Market Rate of Return

To calculate the market rate of return is based on the Stock Price Index (CSPI), by the formula: (Tandelilin, 2010)

Description:

$$
X=R m=\frac{\mathrm{JCI}(\mathrm{t} 1)-\mathrm{JCI}(\mathrm{t} 0)}{\mathrm{JCI}(\mathrm{t} 0)}
$$

$\mathrm{X}=\mathrm{Rm}=$ Market Rate of Return ( $\mathrm{R}$ is based on the stock price index)

$\mathrm{JCI}(\mathrm{tl})=$ composite stock price Index period now

$\mathrm{JCI}(\mathrm{t} 0)=$ composite stock price Index period ago

- Calculate Return-Free Risk

Risk free or known by the rate of return risk-free refers to the rate of return of financial assets without risk. Interest rate securities issued by the government is the basis of measurement used, hereinafter referred to as the Certificate of Bank Indonesia (SBI). The formula used is: (Alifiani, 2017)

$$
R f=\frac{\sum_{i=1}^{n} \text { the Level of Interest Rates on SBI }}{n}
$$

Description:

$\mathrm{Rf} \quad=$ Return-Free Risk

$\sum \mathrm{SBI}=$ value of SBI

$\mathrm{n} \quad=$ number of data

- Calculate Level of Systematic Risk of Individual Stocks

After calculating the profit level of the market $(\mathrm{X})$ and the profit level of an individual stock $(\mathrm{Y})$, then it can be also calculated the beta ( $(3)$ or the risk of each stock, i.e. by the formula: (Putri, 2015)

$$
B \mathrm{i}=\frac{\mathrm{N} \sum \mathrm{XY}-\left(\sum \mathrm{X}\right)\left(\sum \mathrm{Y}\right)}{\mathrm{N} \sum \mathrm{X}^{2}-\left(\sum \mathrm{X}\right)^{2}}
$$

Description:

$B \mathrm{i}=$ Beta or risk stock

$\mathrm{N}=$ Number of periods analyzed

$\mathrm{X}=\mathrm{Rm}=$ Rate of market advantage ( $\mathrm{R}$ is based on the stock price index).

$\mathrm{Y}=\mathrm{Ri}=$ Rate of profit each penlsahaan $(\mathrm{R}$ is based on the profits of stock of the individual/respective company.

- Calculate Rate of Return Expectations

The rate of return expectations of a stock in the CAPM model, namely by the formula: (Tandelilin, 2001)

$$
E(R i)=R f+(R m-R f) * ß i
$$


Description:

$\mathrm{E}(\mathrm{Ri})=$ the Rate of return expectations on the $\mathrm{i}$

$\mathrm{Rf}=$ The risk-free profit (average SBI)

$\mathrm{Rm} \quad=$ the Rate of return the market

$\mathrm{Bi} \quad=$ Beta of the risk of individual stocks

\section{Results and Discussion}

Table 1. List of 5 Companies of Automotive Industry listed in Indonesia stock Exchange (BEI)

\begin{tabular}{cll}
\hline NO & \multicolumn{1}{c}{ CODE } & \\
\hline 1 & ASII & ASTRA INTERNATIONAL Tbk. \\
2 & BRAM & INDO KORDSA Tbk. \\
3 & IMAS & INDOMOBIL SUKSES INTERNATIONAL Tbk. \\
4 & AUTO & ASTRA OTOPARTS Tbk. \\
5 & GJTL & GAJAH TUNGGAL Tbk. \\
\hline
\end{tabular}

\section{Result of Analysis of Rate of Return of Individual Stocks}

Return of individual stocks ( $\mathrm{Ri}$ ) can be calculated by reducing the price of the stock today with the share price of the previous day and compare with the stock price the day before. Following the results of the calculation of the return of individual stocks 5 company industry automotive listed on the stock exchange for the period of January 2021 - May 2021.

Table 2. Return of Individual Stocks 5 Companies of Automotive industry

\begin{tabular}{cccccccc}
\hline \multirow{2}{*}{ No } & \multirow{2}{*}{ Code } & \multicolumn{5}{c}{ Return } & \multirow{2}{*}{ E Ri } \\
\cline { 3 - 7 } & & January & February & March & April & May & A \\
\hline 1 & ASII & -0.015661325 & -0.118734533 & -0.019755544 & 0.045821262 & -0.063758588 & -0.172088624 \\
2 & BRAM & -0.073577435 & -0.015722574 & -0.000647796 & 0.052250222 & 0.029301973 & -0.008395611 \\
3 & IMAS & -0.467769486 & 0.403981623 & -0.195501617 & 0.048557017 & -0.17018656 & $\mathbf{- 0 . 3 8 0 9 1 9 0 2 3}$ \\
4 & AUTO & -0.099761792 & 0.040599309 & 0.105548764 & 0.01187553 & -0.02495357 & 0.033308241 \\
5 & GJTL & 0.076119325 & 0.217085412 & 0.038505524 & 0.03225125 & -0.032273316 & $\mathbf{0 . 3 3 1 6 8 8 1 9 5}$ \\
\hline
\end{tabular}

Source: Data processed by Microsoft Excel

Based on Table 2, it can be seen that the share rate of return (Ri) and the highest in PT Gajah Tunggal Tbk. That is equal to 0,331688195 and to stock returns (Ri) and lowest on PT Indomobil Sukses International Tbk. that is equal to $-0,380919023$.

\section{Result of Analysis of Market Returns}

In the calculation of return on the market, then the INDEX used in this calculation. With the use of the INDEX is because it is considered to represent the entire transaction activity existing shares on the stock exchange.

Table 3. Market Return INDEX January - May 2021

\begin{tabular}{lcr}
\hline \multicolumn{1}{c}{ Period } & Close Price & Return Market \\
\hline January & 5862.352051 & \\
February & 6241.795898 & $\mathbf{0 . 0 6 4 7 2 5 5 3 1}$ \\
March & 5985.521973 & $\mathbf{- 0 . 0 4 1 0 5 7 7 2 3}$ \\
April & 5995.616211 & 0.001686442 \\
May & 5947.462891 & -0.008031421 \\
\hline \multicolumn{2}{c}{ the Value of the highest } & 0.064725531 \\
\multicolumn{2}{c}{ Value Low } & -0.041057723 \\
E (RM) & 0.004330707 \\
\hline
\end{tabular}

Source: Data processed by Microsoft Excel 


\section{Result of Analysis of Risk-Free}

Data rate of $\mathrm{BI}$ rate in this study is used as an indicator in calculating the level of Risk Free (Rf), result of the calculation of the Risk Free rate is as follows:

Table 4. Result of Calculation of Risk Free January - May 2021

\begin{tabular}{lc}
\hline \multicolumn{1}{c}{ The period of the } & Rf \\
\hline January & 3.75 \\
February & 3.5 \\
March & 3.5 \\
April & 3.5 \\
May & 3.5 \\
Risk Free & $\mathbf{3 . 5 5}$ \\
\hline Source:
\end{tabular}

\section{Results of Analysis of Calculation of Systematic Risk of Individual Stocks}

Table 5. Results of Analysis of Calculation of Systematic Risk of Individual Stocks

\begin{tabular}{ccccc}
\hline No & Code Issuer & Covar $\mathbf{( R i , R m )}$ & Var $\mathbf{R m}$ & Beta \\
\hline 1 & ASII & 0.000095810 & 0.000094137 & 1.01776919 \\
2 & BRAM & -0.000003145 & 0.000094137 & -0.033404843 \\
3 & IMAS & 0.000199132 & 0.000094137 & 2.115333731 \\
4 & AUTO & 0.000048432 & 0.000094137 & 0.514487015 \\
5 & GJTL & 0.000195203 & 0.000094137 & 2.073596122 \\
\hline
\end{tabular}

Source: Data processed by Microsoft Excel

\section{Result of Calculation of Rate of Expected Return}

Table 6. Result of Calculation of $\mathrm{E}(\mathrm{Ri})$

\begin{tabular}{ccc}
\hline No & Code Issuer & E (Ri) CAPM \\
\hline 1 & ASII & 6148.890488 \\
2 & BRAM & -198.150086 \\
3 & IMAS & 12776.03923 \\
4 & AUTO & 3110.047931 \\
5 & GJTL & 12524.02549 \\
\hline \multicolumn{2}{l}{ Source: } & Data processed by Microsoft Excel
\end{tabular}

\section{Classification of Stock}

Based on the calculations that have been done before, then stock can be classified by comparing the $\mathrm{Ri}, \mathrm{E}(\mathrm{Ri})$, and CAPM. If the value of $\mathrm{Ri}>\mathrm{E}(\mathrm{Ri}) \mathrm{CAPM}$ then the shares can be classified as a stock that has a value undervalued. Whereas if the value of $\mathrm{Ri}<\mathrm{E}(\mathrm{Ri}) \mathrm{CAPM}$ then the shares can be classified as a stock that has a value overvalued (Dempsey, 2013). Here are presented the data classification of Stock 5 companies of the automotive industry listed on the stock exchange as follows:

Table 6. Classification of Stock and Recommendation

\begin{tabular}{ccccccc}
\hline No & Code Issuer & Ri & E (Ri) CAPM & Results & Value stated & Decision \\
\hline 1 & ASII & -0.17208824 & -0.058672964 & $\mathrm{Ri}<\mathrm{E}(\mathrm{Ri})$ & Over Valued & Sell \\
2 & BRAM & -0.008395611 & 3.668442525 & $\mathrm{Ri}<\mathrm{E}(\mathrm{Ri})$ & Over Valued & Sell \\
3 & IMAS & -0.380919023 & -3.950273852 & $\mathrm{Ri}>\mathrm{E}(\mathrm{Ri})$ & Under Valued & Buy/Hold \\
4 & AUTO & 0.033308241 & 1.72579919 & $\mathrm{Ri}<\mathrm{E}(\mathrm{Ri})$ & Over Valued & Sell \\
5 & GJTL & 0.331688195 & -3.802286095 & $\mathrm{Ri}>\mathrm{E}(\mathrm{Ri})$ & Under Valued & Buy/Hold \\
\hline
\end{tabular}

Source: Data processed by Microsoft Excel

Based on table 6 , it can be seen that there are 2 companies whose shares are classified as under-valued, while 3 companies included to over-valued. 


\section{Relationship between Individual Rate of Return and Investment Rate of Return}

Based on the analysis and discussion of the highest stock return (Ri) is PT Gajah Tunggal Tbk. That is equal to 0.331688195 and the lowest rate of return (Ri) is PT Indomobil Sukses International Tbk. which is -0.380919023 . From the five automotive companies, the highest average individual return is PT Gajah Tunggal Tbk, followed by PT Astra Otopards, PT Indo Kordsa, PT Astra International Tbk, and the last position is PT Indomobil Sukses International Tbk. The five stocks have different returns, PT Gajah Tunggal Tbk and PT Astra Otopards have positive shares meaning the company is experiencing a profit while PT Indo Kordsa, PT Astra International Tbk, and PT Indomobil Sukses International have negative shares meaning the company is experiencing losses (Kisman \& Restiyanita, 2015).

\section{Individual Stock Systematic Risk Calculation Analysis}

Based on the results of the calculation table above, analysis and discussion for the automotive company. After calculating the systematic risk $(\beta)$, the highest (Beta $(\beta)$ is PT Indomobil Sukses Internatioal Tbk while the lowest beta is PT Indo Kordsa Tbk. The four companies are positive while one company is negative. This shows the shares of PT Gajah Tunggal Tbk, PT Astra Otopards, PT Astra International Tbk, and PT Indomobil Sukses International Tbk seem to move in the direction of the up and down of the Market Return (Rm), while the shares of PT Indo Kordsa seem to move in the opposite direction to the rising market return (Rm).

If the beta is averaged, then the average beta is never equal to 1 . This is because the JCI is used as a market portfolio while the average is the sample stocks, not the entire stock. Stocks with a beta $(\beta)$ less than one $(\beta<1)$ usually move slower than the market. Stocks like this are called defensive stocks, while stocks with a beta value of more than $1(\beta>1)$ will usually move faster than market movements, stocks like this are called Aggressive stocks (Hundal, 2019; Susanti, et al. 2020).

Seen in the five automotive company stocks that became defensive stocks, namely PT. Indo Kordsa Tbk and PT. Astra Otopards Tbk where the beta of the shares of the two companies is below $1(1<)$, namely for PT. Indo Kordsa Tbk of -0.033404843 and PT. Otopards Tbk amounted to 0.514487015 . That is, the two companies are moving slower than the market movement. Meanwhile, the shares of automotive companies whose movements are aggressive, namely PT. Gajah Tunggal Tbk, PT. Astra International Tbk and PT. Indomobil Sukses International Tbk each has a value of 2.073596122, 1.01776919 and 2.115333731 where the stock beta of the three companies is more than $1(>1)$. That is, PT. Gajah Tunggal Tbk, PT. Astra International Tbk and PT. Indomobil Sukses International Tbk moves faster than the market moves.

This is the same as previous research. As research conducted by Hidayati (2014) shows the results that PT Astra International Tbk has a return rate with a positive stock value which means profitable. Then research conducted by Liwe et al. (2021) who conducted a study with the title "Assessment of Stock Investment Decisions in the Application of Sales Tax Incentives on Luxury Goods (PPnBM) for Go Public Companies in the Covid-19 Era, Pandemic Case Studies in Automotive Sector Companies) with the object Data of automotive sector companies listed on the Indonesia Stock Exchange (IDX) until April 2021 shows that shares in PT. Astra International Tbk, P'T. Indo Kordsa Tbk, PT. Indomobil Sukses Internasional Tbk, PT. Astra Otoparts Tbk, and PT Gajah Tunggal Tbk have a low level of risk.

\section{Expected Rate of Return Analysis}

Based on the calculation, the company with the highest rate of return is PT Astra Interasioal Tbk by 6148.890488 and the lowest return is -98.150086 by PT Indo Kordsa Tbk. Of the five companies, there are four positive companies and one negative company. Companies with positive results, the company makes a profit, if the value is negative, the company suffers a loss (Ayub, et al. 2020; Wu, et al. 2017). The four companies with positive scores are: Pt Astra International Tbk. amounting to 6148.890488, Astra Otoparts Tbk amounting to 3110.047931, Gajah Tunggal Tbk. as many as 12524,02549, and Indomobil Sukses International Tbk. amounting to 12776,03923 
because the four companies have a positive value so that the four companies earn profits. On the other hand, PT Indo Kordsa Tbk obtained a negative result of -1981.50086 so that the company did not make a profit.

\section{Efficient and Inefficient Automotive Company Stock Classification}

Stocks are said to be inefficient if the risk is greater than the expected return, while stocks are said to be efficient if the amount of risk is less than the expected return. Based on the calculation of the five companies, there are 2 companies that are not worth buying and 3 companies that are worth buying. PT Indomobil Sukses Internasional and Gajah Tunggal have Ri $>\mathrm{E}(\mathrm{Ri})$ namely ($0.380919023>-3950273852)$ and $(0.331688195>-3.802286095)$, so the shares are not efficient in other words the company is not worth buying and if it already has it is better to sell . Unlike Astra International, Indo Kordsa, and Asta Ortoparts, they have Ri $<$ E(Ri) namely $(-0.17208824<$ $0.058672964),(-0.008395611<3.668442525)$, and $(0.033308241<1.72579919)$ so that the three stocks can be categorized as trading efficient and feasible to be bought.

The CAPM assists investors in calculating the non-diversification risk in a portfolio and comparing it to the predicted rate of return. Based on the above data processing, we can easily see which companies are profitable and which companies are losing. Investors will find it easier to determine which companies are worth buying or keeping, and which companies are not worth buying (Agouram, 2020). So it can be concluded that the processed data is in accordance with the understanding of the CAPM (Capital Asset Pricing Model).

\section{Implication and Conclusion}

1. Based on the results of research by comparing the value of $E(\mathrm{Ri})$ with $E(\mathrm{Ri})$ has a directly proportional relationship, meaning that the higher the value of, then the stock return $(\mathrm{E}(\mathrm{Ri}))$ will be high as well. From the 5 companies, there are 2 companies that are in the Undervalued category and 3 companies that are in the overvalued category. This means that investors who will invest in companies engaged in the automotive industry can decide to buy shares of the companies PT Indomobil Sukses Internasional Tbk and PT Gajah Tunggal Tbk, because they are classified as undervalued. Meanwhile, investors who want to invest in shares are not advised to buy shares of companies that are in the overvalued category, but are advised to sell them to investors who already have shares in the company (Pebriani, et al. 2018).

2. Shares in automotive and component companies that go public on the IDX are defensive in January-May 2021 is PT. Indo Kordsa Tbk and PT. Astra Otoparts Tbk where the risk or beta of the shares belonging to the two shares is below 1, namely PT. Indo Kordsa Tbk of 0.033404843 and PT. Astra Otoparts Tbk amounted to 0.514487015. That is, the two companies are moving slower than the market movement. Meanwhile, shares in automotive and component companies that go public on the BEI that were aggressive were PT. Indomobil Sukses Internasional Tbk amounted to 2.115333731, PT Gajah Tunggal Tbk amounted to 2.073596122, and PT. Astra International Tbk of 1.01776919 where the risk or beta of the stock is more than 1 . It means that the three companies are moving faster than the market movement.

3. From the five companies studied, one company, namely PT. Astra International Tbk, PT. Indomobil Sukses Internasional Tbk, PT. Astra Otoparts Tbk, and PT Gajah Tunggal Tbk have a positive rate of return with a positive share value meaning profitable, while PT. Indo Kordsa Tbk has a low rate of return with a negative stock value, meaning the company suffers a loss.

4. Result of this study indicate that PT. Astra International Tbk, PT. Indo Kordsa Tbk, PT. Astra Otoparts Tbk shows an overvalued value because $\mathrm{Ri}<\mathrm{E}(\mathrm{Ri})$ which means that the right decision is to sell the shares. While PT. Indomobil Sukses Internasional Tbk and PT Gajah Tunggal Tbk show an undervalued value because $\mathrm{Ri}>\mathrm{E}(\mathrm{Ri})$ which means that the right decision is to buy/hold shares (Azizah, 2007). 
For future research, the researchers may consider similar research topics in other industries. The service and tourism industries could be severely impacted by the Covid-19 pandemic. This is a challenge for researchers and management practices to identify patterns of stock movement and the effectiveness for investors to sell or buy their shares. In addition, in industries prone to being affected by the pandemic, it is hoped that the financial approach and CAPM will be able to predict the positive prospects of stock price movements so as to provide good sentiment from market perceptions of economic revival in both the real and macro and monetary sectors.

\section{References}

Agouram, J., Anoualigh, J., \& Lakhnati, G. (2020). Capital asset pricing model (CAPM) study in mean-gini model. International Journal of Applied Economics, Finance and Accounting, 6(2), 57-63.

Alifiani, M. A. (2017). Analisis Return Dan Risk Atas Investasi Saham Pada Perusahaan Otomotif Dan Komponen Go Public Di Bursa Efek Indonesia Periode 2014-2016. Jurnal Studi Manajemen Bisnis, 1(1).

Ayub, U., Kausar, S., Noreen, U., Zakaria, M., and Jadoon, I. A. (2020). Downside risk-based sixfactor capital asset pricing model (CAPM): A new paradigm in asset pricing. Sustainability, 12(17), 6756.

Azizah, N. (2007). Analisis Capital Asset Pricing Model (Capm) Sebagai Dasar Keputusan Investasi Saham Pada Perusahaan Food And Beverages Yang Terdaftar Di Bursa Efek Indonesia. Equilibrium: Jurnal Ekonomi-Manajemen-Akuntansi, 5(3), 282-301.

Barberis, N., Greenwood, R., Jin, L., and Shleifer, A. (2015). X-CAPM: An extrapolative capital asset pricing model. Journal of Financial Economics, 115(1), 1-24.

Dempsey, M. (2013). The capital asset pricing model (CAPM): the history of a failed revolutionary idea in finance?. Abacus, 49, 7-23.

Hidayati, A. A. (2014). Analisis Capital Asset Pricing Model (CAPM) Terhadap Keputusan Investasi Saham (Studi pada perusahaan-Perusahaan Sektor Perbankan di BEI Tahun 20092011). Jurnal Administrasi Bisnis, 9(1).

Hundal, S., Eskola, A., and Tuan, D. (2019). Risk-return relationship in the Finnish stock market in the light of Capital Asset Pricing Model (CAPM). Journal of Transnational Management, 24(4), 305-322.

Jogiyanto, H.M. (2008). Teori Portofolio dan Analisis Investasi, Yogyakarta: BPFE.

Kisman, Z., and Restiyanita, S. (2015). M. The Validity of Capital Asset Pricing Model (CAPM) and Arbitrage Pricing Theory (APT) in Predicting the Return of Stocks in Indonesia Stock Exchange. American Journal of Economics, Finance and Management, 1(3), 184-189.

Liwe, A. G., Budiarso, N. S., and Pontoh, W. (2021). Penilaian Keputusan Investasi Saham Dalam Penerapan Insentif Pajak Penjualan Atas Barang Mewah (PPNBM) Bagi Perusahaan Go Public Di Era Pandemi Covid-19 (Studi Kasus Pada Perusahaan Sektor Otomotif). Jurnal Ipteks Akuntansi Bagi Masyarakat, 5(1), 1-8.

Pebriani, K., Topowijono, T., and Nurlaily, F. (2018). Penerapan Metode Capital Asset Pricing Model (Capm) Untuk Menentukan Pilihan Investasi Pada Saham (Studi Pada Perusahaan Sektor Consumer Goods Industry Yang Terdaftar Di Bursa Efek Indonesia Periode 20142016). Jurnal Administrasi Bisnis, 57(2), 77-86.

Putri, R. L. (2015). Implementasi Capital Asset Pricing Model (CAPM) dalam Analisis Portofolio sebagai Dasar Keputusan Investasi Saham di Bursa Efek Indonesia. Jurnal Kompilasi Ilmu Ekonomi (KOMPILEK), 6(1), 12-27. 
Septiana, S., Hariyanto, D., and Safitri, H. (2018). Analisis Capital Asset Pricing Model Dalam Pengambilan Keputusan Investasi Saham Studi Kasus: Perusahaan Yang Tergabung Di Indeks IDX30. Jurnal Produktivitas: Jurnal Fakultas Ekonomi Universitas Muhammadiyah Pontianak, 5(1).

Susanti, E., Astuti, A., and Supitriyani, S. (2021). Keputusan Berinvestasi dengan Menggunakan Metode Capital Asset Pricing Model (CAPM) pada Perusahaan Indeks LQ 45 Periode 2015-2019. Jurnal Akuntansi dan Pajak, 21(02).

Susanti, E., Grace, E., and Ervina, N. (2020). The Investing Decisions during the COVID-19 Pandemic by Using the Capital Asset Pricing Model (CAPM) Method in LQ 45 Index Companies. International Journal of Science, Technology \& Management, 1(4), 409-420.

Tandelilin, E. (2001). Analisis Investasi dan Manajemen Portofolio. Yogyakarta: Kanisius.

Tandelilin, E. (2010). Portofolio dan Investasi Teori Aplikasi. Yogyakarta: Kanisius.

Wu, M., Imran, M., Feng, Y., Zhang, L., and Abbas, M. (2017). Review and validity of capital asset pricing model: evidence from Pakistan stock exchange. International Research in Economics and Finance, 1(1), 21.

Yu, H. X. (2017). Capital Asset Pricing Model-investigation and Testing. Journal of Applied Finance and Banking, 7(6), 85. 